telescopes in many ways, but in some respects they are not so good. They give images that are absolutely achromatic, while the other form always has some uncorrected colour. They can be made shorter, and as the light-grasping power is not reduced by the absorption of the glass of which the lenses are made, it is in direct proportion to the surface or area of the mirror. They have not had in many cases the same care bestowed upon either their manufacture or $u_{\mathrm{r}}^{-} \eta$ their mounting as has been given in nearly every case to the refracting telescope. Speaking generally, the mounting of the reflecting telescope has nearly always been of a very imperfect kind-a matter of great consequence, for upon the mounting of the astronomical telescope so much depends. To direct the tube to any object is not difficult, but to keep it steadily moving so that the object remains on the field of view requires that the tube should be carried by an equatorial mounting of an efficient character. The first essential of such a mounting is an axis parallel to the axis of rotation of the earth. The tube, being supported on this, will follow any celestial object, such as a star, by simply turning the polar axis in a contrary motion to that of the earth at the same rate. If we make the telescope to swing in a plane parallel to the polar axis, we can then direct the telescope to any part of the sky, and we have the complete equatorial movement. There are several ways in which this is practically done : we can have a long open-work polar axis supported at top and bottom, and swing the telescope in this, or we can have short strong axes. As examples of the first, I will show you pictures of the mountings designed for Cambridge and Greenwich Observatories some forty years ago by Sir G. Airy, lately and for so long our eminent Astronomer-Royal ; and as examples of the other form, amongst others, the large telescope lately erected at Nice, and also the larger one at Mount Hamilton, California, now under the direction of Prof. Holden.

The plan of bringing all the various handles and wheels that control the movement of the telescope and the various accessories down to the eye end, so as to be within reach of the observer, is carried to the highest possible degree of perfection here, as we can see by an inspection of the picture of the eye end of this telescope. The observer with the reflecting telescope is, with moderate-size instruments, never very far from the floor, but in the case of the Lick telescope he might have to ascend some thirty feet for objects low down in the sky; but, thanks to the ingenuity of Sir Howard Grubb, to whom the idea is due, the floor of the whole Observatory is made to rise and fall by hydraulic machinery at the will of the observer-a charming but expensive way of solving the difficulty, as far as safety goes, but not meeting the constant need of a change in position as the telescope swings round in keeping up with the motion of the object to which it is directed. The great length of the tube of large refractors is well seen in this picture of the Lick telescope ; it suggests flexure as the change is made in the direction in which it points, and the consequent change of stress in the different parts of the tube.

The mounting of the reflector has been treated, if not so successfully, with more variety than in the case of the refractor as we shall see from the pictures I will show you, especially where the Newtonian form is used. The 4 -foot reflector at Melbourne is mounted on the German plan, in a similar way to a refractor, and an almost identical plan has been followed by the makers of the 4-foot at the Paris Observatory. Lassell, who was the first to mount a large reflector equatorially, used a mounting that may be called the forked mounting, the polar axis being forked at its upper end, and the tube of the telescope swinging between the forks : a very excellent plan, dispensing with all counterpoising. Wishing to obtain certain conditions that I thought and think now favourable to the performance of the reflector, I devised a mounting where the whole tube was supported at one end on a bent arm ; a 3 -foot mirror was mounted on this plan in 1879 , and worked admirably. The Newtonian form demands the presence of the observer near the high end of the telescope, and the trouble of getting him there and keeping him safely close to the eye-piece is very great. As we see from the various photographs, several means have been employed to do this, none of them quite satisfactory.

All the refracting telescopes of note in the world are covered by domes that effectually protect them from the weather; these domes are in some cases comparable in cost with the instruments they cover. It is not surprising, therefore, that efforts have been made to devise a means of getting rid of this costly dome and the long movable tube.
It was suggested many years ago that a combination of plane mirrors could be used to direct light from any object into a fixed telescope. This idea in a modified form has often been used for special work, one plane mirror being used as we see in the picture on the screen to throw a beam of light into a telescope fixed horizontally ; for certain kinds of work this does admirably, but the range is restricted, as can be easily seen, and the object rotates in the field of view as the earth goes round. The next step would be to place the telescope pointing parallel to the axis of the earth and send the beam of light into it from the mirror, which could now be carried by the tube so that by simply rotat ing the tube on its own axis the object would be kept in the field of view. Sir Howard Grubb makes a small telescope on this plan, and some years ago proposed a somewhat similar plan. A sketch of this plan I will show you. You will see, however, that here again the range is restricted, and, to use the telescope, means would be required to constantly vary the inclination of the small mirror at one-half the rate of inclination of the short tube carrying the object-glass.

By the use of two plane mirrors, however, the solution of the problem of a fixed rotating telescope tube placed as a polar axis is solved. By having such a telescope with a plane mirror at an angle of $45^{\circ}$ to the axis of the telescope in front of the objectglass, we can, by simply rotating the telescope, see every object lying on the equator; and by adding another similar plane mirror at an angle of $45^{\circ}$ to the axis of the telescope, as bent out at right angles by the first plane mirror, and giving the mirror a rotation perpendicular to this axis, we obtain the same power of pointing the telescope as we have in the equatorial. The idea of doing this was published many years ago, but it was left to the skill and perseverance of M. Løewy, of the Paris Observatory, to put it into practical use. He devised, and had made, a telescope on this principle, of $10 \frac{1}{2}$ inches aperture, which was completed in 1882 . It has proved itself an unqualified success, and many other larger ones are now being made in Paris, including one of 23 inches aperture, now nearly completed, for the Paris Observatory.

A lantern copy of a drawing of this latter telescope will be thrown on the screen, in order that you may see what manifest advantages exist in this form of telescope. There is but one objection that can be urged-that is, the possible damage to the definition by the plane mirrors; but this seems, from what I have seen of the wonderful perfection of the plane mirrors made by the Brothers Henry, to be an unreasonable one-at any rate not an insurmountable one. In every other respect, except perhaps a slight loss of light, this form of telescope is so manifestly superior to the ordinary form that it must supersede it in time, not only for general work, but for such work as photography and spectroscopy.

\section{ANNUAL VISITATION OF GREENWICH OBSERVATORY}

THE Report of the Astronomer-Royal to the Board of Visitors of the Royal Observatory, Greenwich, was read at the Annual Visitation on June 7. The Report presented refers to the year 1889 May II to 1890 May 10, and exhibits the state of the Observatory on the last-named day.

With respect to astronomical observations it is noted that, at the request of Dr. Gill, special attention has been paid to the oppositions of the minor planets Victoria and Sappho. Victoria has been observed 15 times on the meridian, and Sappho 9 times; while 244 observations have been made of $4 \mathrm{r}$ comparison stars for Victoria, and $15 \mathrm{I}$ observations of 42 stars for Sappho. At the request of Dr. Auwers, observations of the Sappho stars will be renewed in the autumn of this year, and an investigation made of the variation of personality with magnitude, for use in reducing the observations to a uniform system.

The Lassell, south-east, Sheepshanks, and Shuckburgh equatorials are in good working order. Great difficulty has been experienced at times in turning the south-east dome, and a careful examination shows that this may be largely due to the irregular shape of the cannon balls on which it rolls, and to a sagging of the dome curb in some parts.

The tube for the 28 -inch refractor, which is of special construction, has been made by Sir H. Grubb in preparation for the object-glass which is now being figured. The experimental 
4 -inch object-glass referred to in the last Report was mounted on the Sheepshanks equatorial, and 18 photographs were taken with it last summer, the lenses being separated for photographic achromatism, and the crown lens reversed to correct for the spherical aberration introduced by the separation. The best distance of separation was determined, and the photographs obtained were found to be quite satisfactory. The completion of the 28 -inch object-glass has been delayed presumably by the pressure of work on the I3-inch photographic telescopes, which have engaged so much of Sir H. Grubb's attention, but it is hoped that the new refractor will be ready for mounting very shortly.

The 13-inch photographic refractor, with ro-inch guiding telescope, by Sir H. Grubb, has been lately mounted in the new 18 -foot dome, and one or two trial photographs have been taken with it.

Since the date of the last Report, 14 occultations of stars by the moon (9 disappearances and 5 reappearances) and 13 phenomena of Jupiter's satellites have been observed with the equatorials, or with the altazimuth. These observations are completely reduced to the end of 1889 . The occultation of Jupiter by the moon on August 7 was observed with 5 instruments.

Comets have been observed with the Sheepshanks equatorial on II nights as follows: Comet $a \mathbf{1 8 8 9}$ on 6 nights, Comet $d$ 1889 on I night, Comet $a$ I 890 on 4 nights.

The conjunction of Mars and Saturn on September 19 was observed with the south-east equatorial under favourable atmospheric conditions, and nineteen differential observations made of right ascension and north polar distance.

As regards spectroscopic and photographic observations, 457 measures have been made of the displacement of the $F$ line in the spectra of 36 stars, and 20 of the $b$ line in the spectra of 5 stars for determinations of motions of approach or recession. Observations of Algol on 7 nights confirm, as far as they go, the previous results indicating orbital motion. The observations of Spica made in past years are found by Prof. Bakhuyzen to be tolerably well represented on the hypothesis of orbital motion with a period of 4 days 0.386 hours, which agrees well with that recently discovered by Dr. Vogel with his photographic method. As the series of observations with the I $2 \frac{3}{4}$-inch refractor (extending over I5 years) will be shortly brought to a conclusion, it is proposed to discuss them with a view to the detection of orbital motion. The spectra of $R$ Andromeda, $\chi$ Cygni, and Uranus, have been examined on several occasions, and Comet $e$ I 889 on I night.

The sun has been free from spots on 2 II days in the year 1889, the longest spotless period being October 23 to December II. There were also eight other spotless periods of more than a fortnight. The mean daily spotted area in 1889 was 78 , as compared with 89 for 1888 : but the mean daily area for the latter half of the year was nearly twice as great as for the earlier half, being I03 as compared with 53. Again, the mean distance of spots from the equator was $5^{\circ} .46$ in the first six months, and $14^{\circ} .72$ for the last six ; and both these facts thus point to the middle of the year 1889 as a well-defined date for the sunspot minimum.

The following are the principal results for the magnetic elements for 1889:-

\begin{tabular}{|c|c|}
\hline $\begin{array}{l}\text { Mean declination } \ldots \\
\text { Mean horizontal force }\end{array}$ & $\left\{\begin{array}{l}\ldots \quad \ldots \quad \ldots \quad \text { i } 34^{\prime} \cdot 9 \\
3 \cdot 9494 \text { (in British units). } \\
\mathbf{1} \cdot 82 \text { I0 (in metric units). }\end{array}\right.$ \\
\hline$\cdots$ & $\left\{\begin{array}{l}6 \\
6 \\
6\end{array}\right.$ \\
\hline
\end{tabular}

In the year 188 , there were only two days of great magnetic disturbance, but there were also about twenty other days of lesser disturbance, for which tracings of the photographic curves will be published, as well as tracings of the registers on four typical quiet days.

The mean temperature of the year 1889 was $48^{\circ} \cdot 8$, being $0^{\circ} \cdot 4$ below the average of the preceding 48 years. The highest air temperature in the shade was $86^{\circ} .6$ on August $\mathrm{I}$, and the lowest $18^{\circ} .7$ on March 4. The mean monthly temperature in 1889 was below the average in all months excepting May, June, and November. In February and December it was below the average by $2^{\circ} \cdot 4$ and $2^{\circ} \cdot 2$ respectively, and in May above by $3^{\circ} \cdot 9$.

NO. IO77, VOL. 42$]$
The mean daily motion of the air in 1889 was 245 miles, being 39 miles below the average of the preceding 22 years. The greatest daily motion was 736 miles on October 7 , and the least 25 miles on September 3. The greatest pressure registered was 15 lbs. on the square foot on October 7 .

The number of hours of bright sunshine recorded during $\mathbf{1} 889$ by the Campbell-Stokes sunshine instrument was I 156 , which is about 146 hours below the average of the preceding 12 years, after making allowance for difference of the indications with the Campbell and Campbell-Stokes instruments respectively. The aggregate number of hours during which the sun was above the horizon was 4454 , so that the mean proportion of sunshine for the year was $0 \cdot 260$, constant sunshine being represented by $\mathbf{I}$.

The rainfall in 1889 was 23.3 inches, being $1 \cdot 3$ inches below the average of the preceding 48 years.

It was mentioned in the last Report that the Indian invariable pendulums had been mounted in the Record Room under General Walker's supervision. The three pendulums have each been swung 8 times, at pressures of both 2 inches and 27 inches, and the observations completely reduced, giving the following results for number of vibrations in a mean solar day, reduced to vacuum, a temperature of $62^{\circ}$, an infinitely small arc, and sea-level the corresponding values obtained at Kew being appended for comparison :--

$$
\begin{aligned}
& \text { Pendulum. }
\end{aligned}
$$

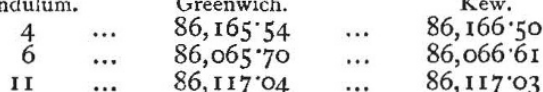

The tabulation of results for the period of the fifty years of observations will be completed at the end of this year, and will be useful for many purposes. In the twenty years' meteorological reductions, the values were grouped generally in months, mainly for the determination of diurnal inequalities of the thermometer and barometer. In the tables of meteorological averages now proposed, however, the values will be grouped by days, so as to exhibit mean values for each day of mean daily temperature, maximum, minimum, barometer, velocity of wind, frequency of gales, rainfall, and cloud, obtained from the Greenwich observations of fifty years, 1841-90.

\section{UNIVERSITY AND EDUCATIONAL INTELLIGENCE.}

CAMBRIDGE.-The following are the speeches delivered by the Public Orator (Dr. Sandys, tutor of St. John's College) in presenting Sir Andrew Clark, Mr. Jonathan Hutchinson, Dr. John Evans, Prof. Sylvester, and Mr. A. J. Ellis for honorary degrees on June ro:-

Salutamus deinceps salutis ministrum, Aesculapii e filiis unum, quem idcirco praesertim Machaona nominaverim quod saeculi nostri oratorum cum Nestore ipso totiens consociatus est ; - nisi forte, Romano potius exemplo delectatus, mavult Asclepiadis illius disertissimi nomen mutuari, quo medico et amico utebatur Lucius Licinius Crassus, saeculi sui oratorum eloquentissimus. In re publica partium liberalium studiosus, in re privata liberali tate singulari insignis, non modo medicinae sed etiam philosophiae et religionis penetralia ingressus est. Etiam antiquos meministis quondam non de corporis tantum salute sed etiam de rebus fere omnibus quae vitam anxiam et sollicitam reddant, ab ipso A esculapio solitos esse oracula exposcere. Viri talis igitur, velut iurisconsulti Romani, domus, est velut civitatis oraculum, unde cives eius, ut Apollo Pythius apud Ennium dicit, consilium expetunt, non salutis tantum sed etiam "summarum rerum incerti," quos incepti certos "compotesque consili dimittit." Ergo virum, quem aut litterarum aut scientiae aut medicinae doctorem nominare potuissemus, iuris doctorem non immerito creamus.

Duco ad vos medicinae professorem emeritum, Regii Medicorum Collegii Londinensis praesidem, baronettum insignem, suavem, eruditum, eloquentem, ANDREAM CLARK.

Etiam alter Aesculapii filiorum, Podalirius (nisi fallor), hodie nobis sese praesentem obtulit, quem a fratre suo idcirco disiungere neque possumus neque volumus, primum quod professoris in munere quondam erat collega eius coniunctissimus, deinde quod forte quadam domum vicinam atque adeo proximam incolit, denique quod dignitate non minore Collegio alteri praesidet, ubi 